\title{
Europe rules against stem-cell patents
}

\section{Work with human embryonic stem cells is 'contrary to ethics'.}

\section{BY ALISON ABBOTT}

S tem-cell researchers in Europe are reeling after the Court of Justice of the European Communities issued an opinion last week questioning the ethics of their work and threatening to ban them from patenting procedures that involve human embryonic-stem-cell lines. Some scientists fear that the opinion could also prompt European countries to tighten their legislation on such research, or ban it altogether.

"It's the worst possible outcome," says Oliver Brüstle, director of the Institute of Reconstructive Neurobiology at the University of Bonn in Germany.

The lengthy legal debate was sparked by Brüstle's 1991 patent of a technique to generate nerve cells from established human embryonic-stem-cell lines. The environmental group Greenpeace, based in Amsterdam, challenged the patent in 2004, arguing that the destruction of human embryos involved in deriving the cell lines was "contrary to public order" and breached guidelines set out in the European Patent Convention.

In 2006, Germany's federal patent court in Munich ruled in Greenpeace's favour, so Brüstle appealed to the Federal Court of Justice in Karlsruhe. That court in turn referred the case to the European court (see Nature 462, 265; 2009).

Judge Yves Bot, the case's adjudicator, concluded on 10 March that even if they do not involve the direct destruction of embryos, techniques involving human embryonic-stemcell lines are not patentable because they are tantamount to making industrial use of human embryos, which "would be contrary to ethics and public policy".

Bot's opinion will now be considered by the 13 judges in the European court's Grand Chamber. A final decision is expected in about two months, but a spokesperson for the European court notes that few preliminary opinions are reversed. And although the final decision will not be binding on Germany's federal court, it is likely to sway the German decision.

Brüstle still hopes that his patented work will eventually lead to the generation of nerve cells that could be used to repair damage to the brain or spinal cord. But "if we are not allowed to protect our inventions in Germany, we won't be able to compete in the international market for new disease therapies", he says.

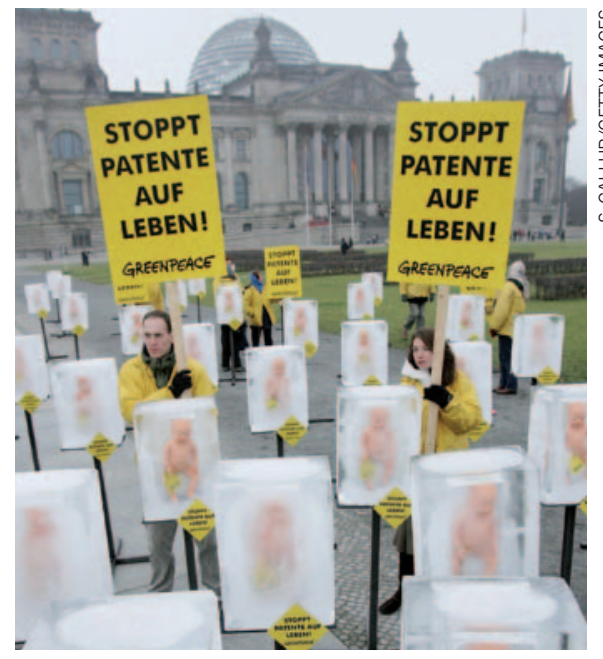

'Stop patents on life', protest Greenpeace activists.

The decision is also likely to cause trouble beyond the issue of patenting. In Europe, laws governing stem-cell research vary widely from country to country. The United Kingdom and Sweden, for instance, are relatively liberal and allow research on newly collected human embryonic stem cells that are still totipotent, meaning that they could develop into a human if they were transplanted into a womb. Others are more restrictive. Germany allows research only on imported human embryonic-stem-cell lines created before May 2007. Such cultured cell lines are merely pluripotent - capable of developing only into defined tissue types. And some countries, including Ireland, have yet to legislate on the issue.

Although Bot noted that pluripotent stem cells cannot be defined as embryos because "they are no longer capable of developing into a complete human being", he did say that the embryonic source of pluripotent cells "cannot be ignored".

As his opinion places such importance on the embryonic origin of the cell lines irrespective of how long ago they were established - some think that the ruling is likely to encourage vacillating countries to introduce restrictive laws or complete bans on the research. Hans Schöler, a stem-cell researcher and director of the Max Planck Institute for Molecular Biomedicine in Münster, Germany, says that such countries are "quite obviously going to refer to a legal opinion at the European level for guidance". - 